\title{
A EXPERIÊNCIA dOS FATOS DE 1964 E 1968 E A POÉTICA de HÉlio Pellegrino
}

The experience of the events of 1964 and 1968 and the poetics of Hélio Pellegrino

\section{Gabriela Kvacek BETELLA ${ }^{30}$ \\ UNESP \\ gabrielakvacek@uol.com.br}

\begin{abstract}
RESUMO: Este ensaio prioriza a produção poética de Hélio Pellegrino (19241988) e procura estabelecer relações entre os seus poemas dos anos de 1940 e os que rodeiam os acontecimentos de 1964 e 1968, especialmente quando o psicanalista mineiro atuou intensamente na imprensa e nas manifestações públicas (como o movimento estudantil), produzindo artigos que atacavam a ditadura, determinantes para a sua prisão em 1969. Um dos objetivos aqui é revelar a dimensão da violência assimilada e explicada por Hélio Pellegrino através dos seus poemas, cuja linguagem passa por um processo de contenção e refinamento paralelo ao desenvolvimento do seu ensaio, na busca da exposição dos fatos, do entendimento do meio pela via filosófica e, ao mesmo tempo, da reavaliação íntima.
\end{abstract}

Palavras-chave: Hélio Pellegrino. Poética. Ensaio. Resistência. Ditadura militar.

Palavras-chave: Poesia. João Cabral. "Paisagens com cupim”. Forma literária.

ABSTRACT: This essay focuses on the poetical production of Hélio Pellegrino (1924-1988) and aims at establishing relationships between his poems from the 1940's and those that permeate the events of 1968 and 1968, especially when the psychoanalyst from Minas Gerais acted intensely in the press and in public manifestations (as in the student movement), producing articles that attacked the dictatorship that were decisive for his imprisonment in 1969. One of the objectives of the present paper is to reveal the dimension of the violence assimilated and explained by Hélio Pellegrino through his poems, whose

${ }^{30}$ Professora Assistente no Departamento de Letras Modernas da FCL-UNESP-Assis.

Revista TextoPoético | ISSN: 1808-5385 | Vol. 21 (2o sem-2016) - p. 146. 
language goes through a process of contention and refinement parallel to the development of his essays in its search for the exposition of the facts, for the understanding of the environment by means of philosophical means and, at the same time, for the innermost reappraisal.

Keywords: Hélio Pellegrino. Poetics. Essay. Resistance. Militar regime.

Há dois tipos de violência, qualitativa $e$ eticamente distintos. A violência do opressor é sempre imoral, liberticida e aviltante da condição humana. A violência do oprimido pode ser ética, libertadora e dignificante. Desconhecer esta diferença é fazer o jogo do opressor, na medida em que se condena, sem discriminação, a violência legítima, a serviço da liberdade.

Hélio Pellegrino

Hélio Pellegrino foi psicanalista, escritor, polemista e sobretudo um grande amigo dos que partilharam sua convivência mais íntima. Seus gestos e seus discursos marcaram reuniões animadas, assim como sua presença deixava qualquer conversa permeada de paixão por causas muito diversas - tudo podia ser tocado e transformado pelo rigor e pela resistência de Hélio, inclusive as declarações de cunho afetivo, como a sua conhecida definição sobre a amizade que unia profundamente o psiquiatra mineiro a Fernando Sabino, Otto Lara Resende e Paulo Mendes Campos:

Há quarenta anos. Nós somos amigos há quarenta anos. Eu acho isso uma coisa espantosa. [...] Eu insisto nessa cronologia porque isso é um fato espantoso num tempo de bombas, de violência, de fratricídio e de homicídio; nós somos imperturbavelmente amigos há mais de quarenta anos. Então eu reivindico para nós nada mais nada menos que o

Revista TextoPoético | ISSN: 1808-5385 | Vol. 21 (2o sem-2016) - p. 147. 
Prêmio Nobel da Paz. Nós constituímos o verdadeiro milagre brasileiro. (RESENDE, 2006).

Sobre a atividade poética, Hélio declarou que tinha "uma inteligência de poeta. Você gesta o poema e ele estoura sem exigir um trabalho braçal. Existe independentemente da sua vontade." A poesia, segundo o psicanalista, é a forma mais nobre da linguagem, antianalítica, "mas um coágulo da existência", com uma plurissignificância inesgotável e sintética (RANGEL, 1981, p. 115). Retomando uma investigação sobre a escrita de Hélio Pellegrino, exploramos aqui alguns aspectos daquela inteligência poética com a consciência de que a produção de Hélio não cabe na definição de poeta bissexto elaborada por Manuel Bandeira em 1946. Do mesmo modo, precisamos advertir que nossa atividade crítica não é especialista na análise e interpretação poética. Com tais ressalvas, esperamos contemplar momentos da produção do autor integrando a poesia à prosa, levando em conta que reside nesse procedimento a essência da escrita de Hélio.

Em 1945 Hélio havia escrito a "Carta-poema", dirigida a Fernando, Otto e Paulo com tom nostálgico, lamentando a separação, a inexorabilidade e as contradições, iniciando uma aposta que nunca terminaria. Numa carta para Otto, no ano seguinte, Hélio exploraria algumas das mesmas incoerências necessárias para o convívio, para a reflexão sobre a vida. É possível tratar-se de uma explicação da gênese do poema aos amigos. Colocadas em prosa íntima, as contradições podem esclarecer as várias formas de discurso praticadas por Hélio, enquanto parecem constituir poema em prosa, como a tentar afirmar que através do contraditório é possível visualizar valores sublimes, e este é o modo estimulante de viver, ou de "perder a vida":

Revista TextoPoético | ISSN: 1808-5385 | Vol. 21 (2o sem-2016) - p. 148. 
Por que isso, meu amigo? Por que é que o tempo carrega consigo não sei que misterioso germe, que aos poucos vai nos dando a impressão de que crescemos, e nos dilatamos, quando na verdade nos dissolvemos, nos liquefazemos, nos perdemos. Por que é que o tempo não é apenas o ar que nos envolve, numa marcha luminosa para a imperecivel unidade?

O erro está em nós mesmos, Otto, na nossa pequenez irremovível, na nossa incapacidade evangélica de "perder a vida", como diz você. Em nome de ilusões, em nome de compromissos com o mundo, em nome de fatalidades biológicas, em nome de gloríolas vãs, em nome da medicina ou do direito, em nome de cartórios, edifícios, praias, orlas, lagoas, em nome da moral e da família, em nome de uma dignidade incompreensivel, em nome especialmente de coisas inomináveis, perdemos aquilo que é o mais puro de nós mesmos, o mais lírico, o mais livre, o mais liberto, o melhor de nós mesmos, o que nos salva da morte e nos transfigura. (PELLEGRINO, 2004b, p. 19-20).

Também é para Otto que Hélio envia, em novembro de 1947, o Livro da Amiga, com 42 poemas que permaneceram quase na totalidade inéditos, dedicados a Maria Urbana Pentagna Guimarães, com quem Hélio se casa no ano seguinte. Apenas oito desses poemas apareceram em edição de 2004, e há boas amostras dos necessários contrastes de imagens e sentimentos para a expressão adequada, como as referências constantes à complexidade contida na simplicidade, ou como no caso sintético do verso "Meu desespero e meu amor se confundem" (PELLEGRINO, 2004a, p. 7).

Fernando, Otto e Paulo transferiram-se para o Rio de Janeiro no início dos anos de 1940. Hélio ficou em Belo Horizonte até 1952. Fez Faculdade de Medicina e dedicou-se à política de modo arrebatador, apoiando a UDN e a candidatura a presidente do brigadeiro Eduardo Gomes, além de ser indicado para a disputa de uma vaga para Deputado Federal em 1945. Foi uma campanha de quinze

Revista TextoPoético | ISSN: 1808-5385 | Vol. 21 (2o sem-2016) - p. 149. 
dias, e por pouco Hélio não foi eleito. No ano seguinte, em viagem ao Rio, Hélio conhece Mário Pedrosa, que será o amigo e companheiro com quem, anos mais tarde, irá se filiar ao Partido dos Trabalhadores. Ainda em 1946, Hélio abandona a UDN por defender a reforma agrária, não incluída nas diretrizes do partido. Passa a ser um dos fundadores da Esquerda Democrática, ligada ao Partido Comunista. Em 1947 forma-se em Medicina, recebendo de Carlos Drummond de Andrade a seguinte saudação, conforme observa Paulo Roberto Pires: "Não sei se você será um médico razoável, mas estou certo de que o seu instinto poético, tão profundo, saberá fazer da medicina uma coisa bela." (PIRES, 1998, p. 15).

No mesmo ano de 1947, Hélio enviou um livro de sonetos seus, cópia única, a Murilo Mendes, numa intenção de diálogo com o poeta e amigo, já residente no Rio de Janeiro e que seria, anos depois, um crítico de arte bastante afastado das exigências acadêmicas, conhecido pela incorporação da expressão poética em seus artigos críticos. Wilson Figueiredo, Autran Dourado e Sábato Magaldi, membros do grupo literário Edifício, com revista de mesmo nome, publicaram dois poemas de Hélio num pequeno livro. São os textos "Deixe que eu te ame" e "Poema do Príncipe Exilado". Este último, dedicado a Mário de Andrade e escrito em setembro de 1944, já trazia na forma a multiplicidade e as antíteses de um raciocínio revelador, maleável, como a querer dar conta de todas as expectativas e conclusões através das imagens utilizadas. Vale reproduzi-lo aqui integralmente, para se notar a assimilação das diretrizes do escritor paulistano, provavelmente devido ao contato que já se estabelecera àquela altura entre Mário e os "vintanistas" mineiros:

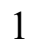

Revista TextoPoético | ISSN: 1808-5385 | Vol. 21 (2o sem-2016) - p. 150. 
Quem sou eu que agora se repete?

Quem sou eu que me debruço nas janelas indevassáveis,

Procurando o movimento das rosas do outro lado?

Quem sou eu que repouso nos divãs esquecidos,

Tranquilo como uma asa que o sono para sempre abriu?

Quem sou eu que atravesso a meia-noite de uma rua,

Tateando com cuidado um corpo sem perfume?

Quem sou eu que me devoro a cada golpe,

Sábio e forte no silêncio dos pequenos quartos sem luz?

Quem sou eu que no bailado do martírio

Uma dama sem rosto abandonou,

Entre rendas e cadeiras de uma cor sem tempo?

Quem sou eu que conhece nos jornais

O segredo de um relógio debruçado

Sobre a cabeça de um morto, claro e aberto como um lírio?

Quem sou eu que na noite da alegria

Visita os velhos pergaminhos de família,

As cortinas da infância, os passos do fantasma,

E sem sono se recolhe nas praias de outro tempo?

Quem sou eu que beijou a lapela do afogado,

A pérola, a gravata, o anel cravejado?

Quem sou eu que de repente abre uma porta,

E se esquece e responde pelo nome: DESVAIRADO!!

Quem sou eu que amanhece de luto entre jornais,

E pela noite traz um cravo e um sorriso no automóvel?

Quem sou eu que respiro entre escuros volumes,

Frios de fria morte encadernada?

Quem sou eu que com um alfinete adormece a amada,

Para cruzar descalço os ladrilhos transversais,

À procura de passado?

Quem sou eu que me guardo nos largos armários de família, Como roupa sem tato, envilecida pelo tempo?

Quem sou eu que me percebo estátua e falcão, Ao lado de um velho fraque que murmura: ela virá!

Quem sou eu que um dia, no encontro das cinco, 
Sem razão exclamou: pura, púrpura!

Sem que ela trouxesse nas mãos a pérola e o segredo?

Quem sou eu que me perco numa esquina,

Desdobrado entre mágoa e cinza fria?

Quem sou eu que atravesso um rio escuro,

E entre as águas revejo um rosto antigo?

Quem sou eu que o luar fere de gritos,

Nas corridas por entre os edifícios

Hirtos de fria cal, quem sou eu que me afogo,

Ajoelhado e sensível nas vertentes,

Entre falas e sinais desconhecidos?

Quem sou eu que viajo num navio

Amargo, a percorrer praias sem nome?

Quem sou eu que é criança entre barqueiros,

Fogo no monte, música na relva,

Orvalho e dor nos lábios desamados,

Parceiro sem jogo, chuva e pranto de invernada,

Sorriso decepando o azul e mais além.

2

A resposta.

No azeite, na cal, na nostalgia: a resposta.

Nos gerânios, nas cartas do correio: a resposta.

Nas ramagens, nas cinzas, no soluço: a resposta.

Nos telhados, nas chuvas que umedecem

a voz dos galos ébrios de esperança: a resposta.

No frio que anoitece uma cidade,

$\mathrm{Na}$ bruma devorando os edifícios: a resposta.

$\mathrm{Na}$ calma sem segredo, no sorriso

Molhando a noite de um calor amigo: a resposta.

Nas sirenes das torres, na conversa

De um suicida pelas sacristias: a resposta.

No soluço do piano, no acento

Grave da mão que em chamas se transforma: a resposta.

Nos postais coloridos, no recorte

Revista TextoPoético | ISSN: 1808-5385 | Vol. 21 (2o sem-2016) - p. 152. 
Da amada entre cartazes: a resposta.

No trabalho das mãos, no corpo agudo

De injustiças e golpes: a resposta.

No sangue do oprimido, na bandeira

Que do Oriente nasce como estrela: a resposta.

No trigo para todos, no ruído

Das carruagens de pão na madrugada: a resposta.

No ódio pelo suor, na voz que sobe

De cifras congeladas: a resposta.

No vinho da traição, na mesa branca

Onde gordos convivas se divertem: a resposta.

$\mathrm{Na}$ casa em construção, nos pulmões exauridos

De fuligem e de olhos perfurados: a resposta.

Nos cânticos, na púrpura dos bispos,

Nas igrejas, no aço dos martírios: a resposta.

$\mathrm{Na}$ água que golpeia o corpo aberto,

$\mathrm{Na}$ camisa sem sangue do afogado: a resposta.

$\mathrm{Na}$ mão que arranca o cetro do bandido,

Falso senhor dos campos: a resposta.

$\mathrm{Na}$ esperança dos olhos, no sorriso

Da boca de criança em tempo novo,

Nas auroras sem gosto de alga e peixe

Soterrados pela guerra: a resposta.

Setembro, 1944 (PELLEGRINO, 1947, p. vii-xvi).

As sensações confundidas pelas lembranças despertadas intensificam-se na segunda parte do poema, onde também se incorpora o sentimento de justiça, a partir do eu-lírico e a busca de sua verdade, até a justiça coletiva. É possível notar evocações de Mário de Andrade, tanto no "desvairado" pelo qual o eu-lírico diz atender, quanto numa presença de "Eu sou trezentos..."

${ }^{31}$ Eu sou trezentos...

(7-VI-1929)

Revista TextoPoético | ISSN: 1808-5385 | Vol. 21 (2o sem-2016) - p. 153. 
"resposta", mas pela mesma disposição da busca, que em Hélio ultrapassa a dimensão lírica. O poema dedicado ao amigo revela um esforço do eu-lírico de entender-se utilizando a palavra que baseia o seu meio. O sujeito sai de sua dimensão reduzida a si mesmo, dos limites do subjetivo, segundo o sentido mais tradicional do gênero lírico, para alcançar-se e definir-se, ao máximo, no mundo objetivo. Isso quer dizer que a busca poética não contempla a linguagem cifrada e sintética, e vai na direção do exagero dissertativo. Essencialmente, as manifestações líricas de Hélio mantêm as características essenciais cuja tônica é a expressão individual. No entanto, seu fazer poético segue uma trajetória orientada pelo entendimento da realidade que o circunda, e por uma necessidade insaciável de explicá-la.

Theodor Adorno destaca aspectos do "vigor coletivo da lírica contemporânea" contrapondo-os aos da lírica tradicional, com o cuidado de averiguar a relação entre as manifestações individuais do sujeito e o sentido coletivo dos aspectos sociais manifestados no gênero lírico (ADORNO, 2003, p. 65-89). O sujeito poético "sempre

Eu sou trezentos, sou trezentos-e-cincoenta, As sensações renascem de si mesmas sem repouso,

Ôh espelhos, ôh! Pireneus! ôh caiçaras!

Si um deus morrer, irei no Piauí buscar outro!

Abraço no meu leito as milhores palavras, E os suspiros que dou são violinos alheios; Eu piso a terra como quem descobre a furto Nas esquinas, nos táxis, nas camarinhas seus próprios beijos!

Eu sou trezentos, sou trezentos-e-cincoenta, Mas um dia afinal eu toparei comigo...

Tenhamos paciência, andorinhas curtas,

Só o esquecimento é que condensa, E então minha alma servirá de abrigo. (ANDRADE, 1966, p. 157).

Revista TextoPoético | ISSN: 1808-5385 | Vol. 21 (2o sem-2016) - p. 154. 
representa um sujeito coletivo muito mais universal" e mantém uma relação "com a realidade social que lhe é antitética", o que exige da interpretação muito mais que a análise dos elementos formais do texto, pois a matéria social pede elucidação, na medida em que está incorporada na composição, assim como o seu tempo histórico (ADORNO, 2003, p. 78). A lírica de Hélio Pellegrino, que ultrapassa seus poemas, parece apostar no sujeito coletivo, embora mantenha a voz muito próxima ao mundo narrado. Noutras palavras, a força poética de Hélio reside na intensificação do eu lírico e na desistência da voz épica para que a matéria social e histórica apareça com mais intensidade, porque vivenciada pelo sujeito.

No "Soneto" de 1947 estão presentes a permanente inquietação e o sentimento que Hélio transformava continuamente em práxis. Imagens e linguagem relativas à destruição, ao sepulcro, tornam o poema significativo no que tange ao período de mudança, de passagem:
Alguma coisa vai despedaçar-se
em mim. Tremem bandeiras degoladas.
Mastros acostumados às lufadas
do mar rangem no rumo de quebrar-se.
O temporal vem perto. Abandonar-se
ao queixume das ondas agitadas
seria bom, talvez. Desesperadas, choram luas enfermas de afogar-se.
E há confusões. E há gritos. E há gemidos
de estrelas violentadas, e alaridos
de cães em bando na procura de ossos.

Revista TextoPoético | ISSN: 1808-5385 | Vol. 21 (2o sem-2016) - p. 155. 
E há vômito nas vagas, e há destroços

amargos, nunca mais recuperados, e há solidão de espelhos sepultados.

Belo Horizonte, 21/8/47 (PELLEGRINO, 1993, p. 151)

Conforme se observa, o poema está em plena utilização da síntese metafórica, porém a flexibilidade das imagens utilizadas por Hélio em seus poemas proporciona uma compreensão disposta a esgotar o tema, e o processo se materializa na recepção do leitor. Nos artigos, ao manipular grande arsenal de imagens e associações, a prática de Hélio será muito parecida. O resultado é a intensidade quase sensorial, aliada à busca de figurações para dominar matéria e espírito, passíveis de identificação pelo leitor. O desenvolvimento do ensaio de Hélio Pellegrino também alia a prática de esgotar os recursos no tocante aos conceitos e explicações dos mesmos (alguns deles, bastante repisados pela crítica social de orientação de esquerda após os anos de 1960). Hélio sempre demonstrou o entusiasmo pela palavra, utilizando-se do máximo dos recursos dela para explicar as causas que abraçou, ou simplesmente para dissertar sobre um tema que julgava importante ou decisivo para o momento em que escrevia. À parte de tudo isso, resta destacar a capacidade de seus artigos permanecerem no tempo.

A partir da década de 1950, Hélio passou a publicar frequentemente em jornais e revistas. Durante o ano de 1952, escreveu em $O$ Globo crônicas não assinadas. Entre 1953 e 1954, colaborou na revista Flan, em duas seções: "Flan sabe tudo" e "Flash psicológico". Contudo, a psicanálise era muito importante para Hélio e, desse período até o início dos anos de 1960, ele se empenha na sua análise didática, primeiro com Iracy Doyle e depois com Anna Katrin Kemper. Os poemas, assim como os artigos, são esporádicos, na imprensa

Revista TextoPoético | ISSN: 1808-5385 | Vol. 21 (2o sem-2016) - p. 156. 
carioca e no Suplemento Literário do Jornal Minas Gerais. Logo após o golpe de 1964, um poema de Hélio reafirma sua lógica multidimensional e lúcida, mesmo sob a intensidade dos sentimentos envolvidos:

\section{A Cólera-Esperança}

Atiro-a contra as quinas erguidas desta madrugada, contra estes edifícios enormes, parados

contra o cinza do céu sujo como o sabão que lava o piso dos botequins ao fim da noite.

Atiro-a contra o cansaço do mundo, contra o meu próprio e inenarrável cansaço, atiro-a em nome da utopia que é minha, a tua, a nossa utopia, atiro-a com raiva, sem estratégia, sem prudência, como hemorragia que se esvai e tinge a calçada com o esguicho do seu incêndio rubro.

Atiro-a para nada, para nenhum resultado do grito que precede o baque do corpo atropelado na rua, atiro-a no ar do mar, na curva corrosiva do azul, à porta dos orfanatos e prostíbulos, atiro-a ao chão como bile sanguinolenta que escorre, como quem cospe um dente arrancado por um murro na boca.

Mas atiro-a, flecha turva, esperança e nojo, vida e cólera, atiro-a com este punho fechado, com esta sede e esta fome, atiro-a com a funda mais funda do meu sonho mais profundo, atiro-a contra argentários e fundiários, opressores e ditadores, atiro-a em meu nome e em nome dos que ainda não têm nome, e em nome dos que em dores e cólicas acordam para o seu nome,

e ao rés-do-chão, em pleno pó, o desentranham.

Rio, 4/64 (PELLEGRINO, 1993, p. 106-107)

Revista TextoPoético | ISSN: 1808-5385 | Vol. 21 (2o sem-2016) - p. 157. 
Escrito no mês seguinte ao golpe militar, o poema representa uma reação contrária à ação totalitária, numa medida que busca equivalência. As imagens que aparecem no centro do texto, associadas ao ato de atirar, misturam evocações de violência e dor contida, visto que são transfigurações do que poderia representá-la. A cólera é, ao mesmo tempo, esperança, e este sentimento bipartido é usado como arma (talvez a única que resta), atirado contra as formas que simbolizam a opressão. Aqui Hélio preconiza, atestando o contraponto que só formularia num ensaio de 1982, uma "violência legítima, a serviço da liberdade", ou seja, a "violência do oprimido", que pode ser "ética, libertadora e dignificante" contra a "violência do opressor", que é sempre imoral, liberticida e aviltante da condição humana" (PELLEGRINO, 1982, p. 3). Acresce-se o fato de que há uma forte marca coletiva ao final do poema - Hélio escrevia quase sempre impulsionado por um fato coletivo.

De 1966 até 1968, Hélio escreve para o Correio da Manhã, ao mesmo tempo em que vai se tornando um líder importante no meio intelectual do Rio, aliado ao movimento estudantil. Os artigos dessa época são publicados no Quarto Caderno do referido jornal. O Correio da Manhã fez história como periódico que denunciou atrocidades cometidas pela ditadura entre 1964 e 1968. O Quarto Caderno surgiu nos anos de 1950, e circulava como versão dominical do Segundo Caderno, numa época em que nem tudo que interessava ao mercado ganhava as páginas de um suplemento cultural. Os textos de Hélio Pellegrino, além de extremamente significativos para o período, são o prenúncio do lote de artigos que o combativo psiquiatra escreverá para a Folha de S. Paulo nos anos de 1980, quando é possível ver a maturidade da argumentação e a conquista da forma do ensaio. Ambos

Revista TextoPoético | ISSN: 1808-5385 | Vol. 21 (2o sem-2016) - p. 158. 
os conjuntos são a melhor amostra do alcance combativo da atitude crítica de Hélio Pellegrino (BETELLA, 2007). Em 1967, por exemplo, Hélio preocupava-se com os riscos do fenômeno social representado pelo papel da televisão em nossas vidas:

O ser humano faz com o mundo uma relação constitutiva, $e$ só pode ser concebido e pensado em função dela. O homem é sua relação com o mundo, e o mundo, por sua vez, é a rede de significações que o homem lança sobre todos os objetos possiveis, num sentido de iluminá-los e articulá-los num todo coerente. Um objeto para mim ganha presença e valor na medida do significado, consciente ou inconsciente que lhe atribuo. Por exemplo, na Índia a vaca é um animal sagrado. Entre nós, quando não existe racionamento, é fonte de leite e gado de corte. Nossa posição filosófica e religiosa é, portanto, de transcendente importância para avaliarmos todos os objetos possiveis, sejam eles vacas ou televisões. Se para os hindus a vaca é um animal sagrado, para nós a televisão é quase isto. Por quê?

[...]

Aos nossos filhos thes damos televisão, não vacas. Ou melhor, damo-lhes vacas que são imagens na televisão, damolhes as sombras das coisas e dos seres, não as próprias coisas e os seres. Por quê? Porque esta é a implícita e diabólica premissa que informa nossa posição racionalista e tecnicista diante do mundo. Somos racionalizadores abstratos, intelectualizadores cruéis, somos assassinos inconscientes das coisas e perdemos, por isto, a possibilidade de desvendálas na sua concretude, na sua transcendência, na sua graça.

$$
\text { [...] }
$$

A filosofia utilitária de nosso século, fruto de otimismo racionalista do século passado, e sua utópica pretensão de transformar o mundo numa fabulosa máquina sem mistério, com vistas a sua dominação e utilização, levou os homens e as culturas a se encerrarem num egoísmo maciço e destrutivo, para o qual só conta o interesse de cada um, em detrimento de tudo o mais. Os homens e as culturas, informados por essa filosofia suicida, montaram e puseram em serviço uma

Revista TextoPoético | ISSN: 1808-5385 | Vol. 21 (2o sem-2016) - p. 159. 
monstruosa engrenagem técnica, inumana na sua esmagadora eficiencia, capaz de apagar o rosto das coisas para melhor torná-las dóceis, servis e usáveis. À cultura tecnicista e utilitária em que vivemos só interessam as abstrações impessoais, os números sem nome, as peças sem destino e sem história, pois tudo que emerge da impessoalidade e da abstração se torna uma excrescência, elas querem rodar e rodar, e triturar e desintegrar e atomizar e uniformizar, e disciplinar e mediocrizar. Esta é a filosofia das engrenagens.

Esta é a filosofia do século. E também, por um lado, a filosofia da televisão, filha dileta do século, bezerro de metal adorado por nós, que traímos as vacas e nos ajoelhamos no altar da eletrônica. Somos o século do totalitarismo e da propaganda, e a força do totalitarismo e da propaganda, em nosso século, alcança níveis apenas imaginados pela mais ousada imaginação humana. O totalitarismo é o resultado de uma filosofia e de uma cultura que esvaziaram os seres de sua transcendência, tornando-os apenas meios, úteis, utilizáveis, exploráveis, e mais nada.

[...]

O perigo da televisão, submissa aos interesses exclusivos do mercado, consiste em que na lama infantil-para falarmos da criança e da televisão - possa ela ajudar a construir uma visão toda ela deformada do mundo, toda uma tábua de valores que nada tenha a ver com os verdadeiros valores que fazem do homem digno, integro, amorável. Se o mundo é só o pasto para meus apetites - e assim passo a avaliá-lo, na medida em que me transformo num consumista inveteradoe se alguma coisa, neste pasto, me resiste, então tenho o direito de agredir e violentar aquilo que me resiste, pois o meu apetite é a minha lei. Daí nasce a apologia direta ou indireta da violência. Minha vocação não é abrir-me ao outro, não é oferecer-lhe o espaço de minha liberdade para que assim possamos nos encontrar, na cálida mutualidade do convívio. Não. Minha vocação é submeter o Outro, é pô-lo ao meu serviço. É conformá-lo, ou deformá-lo-pouco importa, contanto que ele me sirva e eu o possa subjugar, no caso em que me resista, sob o tacão da minha bota. E passo a ser um

Revista TextoPoético | ISSN: 1808-5385 | Vol. 21 (2o sem-2016) - p. 160. 
violento porque me inocularam violência, porque me fizeram e fazem violência, simplificando-me e desrespeitando-me como pessoa. E passo a ser-também e principalmente as crianças! - um pequeno predador perdido na selva que me quer predar, e escolho para o meu projeto o culto da força, a vontade de poder, a euforia mordente da guerra, pela qual e através da qual busco ser o senhor entre escravos. (PELLEGRINO, 2004b, p. 157-164).

O ponto de partida do texto é bem claro: considerando a posição filosófica e religiosa ocidental, quais as causas e consequências da desmedida redenção propiciada pelo aparelho de televisão a difundir imagens casas adentro? A simbologia das engrenagens retorna, desta vez para definir a filosofia "utilitária, predatória e voraz", noutras palavras, o modo de vida do homem do século XX. E já que o autor havia mencionado religião, uma imagem de traição das vacas e genuflexão no altar da eletrônica precede ideias compostas com grande teor de afinidade e sequência, resultando um jato de reflexões que compõem o texto.

Em contato com essas considerações, cerca de quarenta anos após terem sido escritas, observamos a atualidade das mesmas através da capacidade de compreender a relação do fenômeno de massa, ancorado no "totalitarismo da propaganda", com a existência humana moderna, "utilitária e predatória", mas sobretudo esquecida do sentimento igualitário com o Outro. Nem precisamos mencionar o poder alcançado pelo simulacro oferecido pela televisão, verdadeira ameaça às crianças que crescem (e cresceram, de fato) sem um verdadeiro contato com setores importantes da vida, a despeito de os conhecerem e até mesmo comentarem sobre eles. Vemos aqui o retrato de uma geração nascida por volta de 1968.

Revista TextoPoético | ISSN: 1808-5385 | Vol. 21 (2o sem-2016) - p. 161. 
Segundo Hélio Pellegrino, perdemos o respeito pelo Outro devido à superposição das várias faces do consumo, coisa que nos deixa meio tontos, propícios a desvios. Seu raciocínio é exaurido em explicações e acompanha a trajetória da violência do utilitarismo disfarçado de benefício do tecnicismo na sociedade, até que este deságua na impessoalidade e, finalmente, num "egoísmo maciço e destrutivo", nos quais se encerram as pessoas e, por extensão, toda uma cultura. Para Hélio os homens teriam montado uma eficiente estrutura capaz de massacrar a diferença, a criatividade, a imaginação. A ironia composta no final do trecho destacado é o recurso que potencializa as informações arroladas no texto, desde o fato do perigo representado pela televisão até, e principalmente, o raciocínio desenvolvido com perspicácia e, como em outros artigos de Hélio, sem condescendência.

Os acontecimentos políticos e sociais de 1968 foram revisitados por Zuenir Ventura, no aclamado 1968: o ano que não terminou, de 1988. Hélio Pellegrino protagoniza diversas cenas, especialmente no período entre março e junho, ou seja, entre a morte de Edson Luís (28 de março) e a Passeata dos Cem Mil (26 de junho). Destacamos dois episódios marcantes no livro de Ventura: o encontro com o governador Negrão de Lima e a audiência com Costa e Silva.

O dia 21 de junho de 1968 ficou conhecido como "a sexta-feira sangrenta", em que cerca de 400 estudantes foram massacrados pela humilhação da polícia no campo de Botafogo. Na quarta-feira seguinte, seria realizada a Passeata dos Cem Mil. No fim de semana que separou as duas datas, uma assembleia de intelectuais, artistas e jornalistas decidiu encontrar o governador no Palácio Guanabara, utilizando-se do estratagema de cobrar uma promessa de campanha do então candidato Negrão de Lima, que teria afirmado aos eleitores que, em seu governo, "quando tocar a campainha de sua casa de madrugada,

Revista TextoPoético | ISSN: 1808-5385 | Vol. 21 (2o sem-2016) - p. 162. 
pode ficar certo de que é o leiteiro" (VENTURA, 1988, p. 146). Uma segunda proposta, também aprovada, planejava uma manifestação popular, ampla, autorizada pela polícia, bem representativa, a ser organizada depois do encontro. No sábado de manhã, Ferreira Gullar, idealizador do evento, e Jânio de Freitas doutrinavam Hélio Pellegrino, escolhido como porta-voz do grupo. A preocupação voltava-se para a exuberância de Hélio. Gullar chegou a aconselhá-lo para que não fosse "italiano".

Por volta do meio-dia, cerca de 300 artistas, escritores, cineastas e jornalistas chegavam ao Palácio. Após um impasse sobre o local em que seriam recebidos pelo governador, todos superlotavam o Salão Nobre, e o porta-voz do grupo começou a falar, de modo a fazer inveja, nos dias de hoje, a qualquer negociador:

Hélio Pellegrino começou a falar com uma coreografia que era só sua: a mão direita na frente, com o polegar e o indicador armados como se estivessem imitando um tiro, os gestos precedendo em algumas frações de segundo a fala, a voz de um possuido e a argumentação contundente, mas nunca hostil, sempre um convite, um aceno, jamais uma imposição.

"Senhor governador Negrão de Lima, eu fui um eleitor seu e posso lhe garantir que a esmagadora maioria dos intelectuais aqui presentes também foram eleitores seus. O senhor ocupa o seu lugar por delegação nossa. O poder que o senhor exerce é também, fundamentalmente, assunto nosso. Por isso aqui estamos para interpelá-lo com respeito, mas com austeridade. Temos a dizer-lhe, nós que somos responsáveis, que os estudantes não são baderneiros. Os estudantes representam hoje a vanguarda mais lúcida, mais limpa e mais corajosa da luta do povo brasileiro contra a opressão do Estado."

$O$ orador relembrou os acontecimentos daquela semana, quando, na quarta-feira, convidados pelo ministro da Educação, os estudantes foram recebidos no MEC por tropas da PM. No dia seguinte, o governo do Estado garantira ao

Revista TextoPoético | ISSN: 1808-5385 | Vol. 21 (2o sem-2016) - p. 163. 
reitor em exercício, Clementino Fraga, que os estudantes poderiam sair da assembleia na Praia Vermelha sem serem incomodados pela polícia. "A polícia simulou uma retirada, os estudantes saíram - fiados na palavra do Senhor Governador e fiados no testemunho dessa palavra dado pelo reitor-mas foram agredidos, espancados, presos, tocaiados, humilhados e ofendidos. Nós vimos fotografias de moças de quatro, de moças com o rosto enterrado na grama do campo de futebol, e isto não nos honra, isto não é correto, não é direito."

Hélio Pellegrino estava em um de seus melhores dias, conciliando a revolta com um tom respeitoso que não dava margem a qualquer revide: "Senhor Governador, a sua palavra não foi respeitada. Isto é lastimável, e como o seu poder emana de nós - pois o senhor é o candidato que elegemos -, e, na medida em que sua palavra não é respeitada, nós estamos desrespeitados, nós queremos lhe pedir uma opção: ou o senhor, conosco, honrando o mandato que nós lhe demos, cumpre sua palavra de candidato, de fazer do Estado da Guanabara um Estado democrático, ou então o senhor opta por estar contra o povo e ao lado daqueles que o fuzilam".

De cabeça baixa, o governador não podia deixar de ouvir aquelas palavras duras, vindas de seus correligionários. $\mathrm{Na}$ campanha, Carlos Lacerda acusara o candidato de ser o resultado da aliança entre "o PC, a Light e o SNI". Era uma acusação de campanha, mas pelo menos um dos três assumia o apoio: o PC-ele e as esquerdas que não anularam seu voto. "Eu não creio, por sua tradição, por toda a sua vida pública, que o senhor faça uma opção tão melancólica. Nós estamos aqui para lhe pedir, ou, melhor, lhe exigir, várias coisas: o senhor tem de dar uma satisfação à opinião pública, que, maciçamente, esteve do lado dos estudantes."

Nessa altura do discurso, Hélio referiu-se a uma violenta nota da PM publicada naquele dia, dia do enterro do soldado Nélson de Barros, morto na "sexta-feira sangrenta", ameaçando represália: "olho por olho". Ele cobrou as promessas do candidato, recordando a história do leiteiro, e pediu que o governo garantisse o livre exercício dos direitos

Revista TextoPoético | ISSN: 1808-5385 | Vol. 21 (2o sem-2016) - p. 164. 
democráticos. "Além do mais, exigimos, porque seu poder é legítimo e não usurpado, libertar os presos, pois há muita gente presa, há um clima de terror e nós não sabemos onde eles estão."

Hélio se referia ao diretor Flávio Rangel e ao arquiteto Bernardo Figueiredo, que estavam presos.

[...]

Esmagado pela argumentação de Hélio Pellegrino, impotente diante da situação de intelectuais presos, o governador Negrão de Lima era a imagem da falta de poder e da incapacidade de reagir. Ele tentava defender a PM explicando que ela às vezes tinha que ser violenta [...]. (VENTURA, 1988, p. 146-148).

Quando a comissão formada durante a Passeata dos Cem Mil vai encontrar o Presidente Costa e Silva, Hélio é novamente o portavoz. Durante a reunião, o marechal revelou que conhecia sua família e, especialmente, sua condição de funcionário público. Além disso, procurou convencer a comissão de que empenhava-se em resolver os problemas e de que seu governo era democrata, dirigindo-se a Hélio e lhe perguntando se não era verdade que o psicanalista escrevia o que queria. Ainda reforçou: "que ditadura é esta em que as pessoas podem gritar abaixo a ditadura?”. Hélio conduziu o debate com muita destreza, pois a comissão exigia a libertação de presos, enquanto o presidente tentava barganhar com o fim das passeatas. Num determinado momento, Hélio inspirou-se nos "latagões de cassetete cercando a sala" e, como um demiurgo da palavra, disse:

- Presidente, vamos supor que, a gente aqui conversando, um daqueles soldados tire o cassetete e venha para cima de mim.

A hipótese era desconcertante, ainda mais quando dramatizada por quem, por palavras e gestos, lembrava mais seus exuberantes ancestrais da Itália do que seus comedidos

Revista TextoPoético | ISSN: 1808-5385 | Vol. 21 (2o sem-2016) - p. 165. 
conterrâneos de Minas. Pode-se imaginar a cara do presidente enquanto o orador continuava:

"O diálogo será impossível. Se sou agredido fisicamente, como posso conversar? É mais ou menos o que está havendo: o governo diz que quer conversar com os estudantes - eu acredito, e isso é meritório, é excelente. Mas as forças da repressão continuam espancando os estudantes no meio da rua. Não pode haver repressão, presidente. É preciso que os ânimos se acalmem e o diálogo se estabeleça." (VENTURA, 1988, p. 177-178).

Em janeiro de 1969 Hélio é preso e levado ao Regimento Caetano de Faria, depois é transferido para o Primeiro Batalhão de Guerra. O inquérito acusava-o de líder comunista e apoiava-se, naturalmente, em vários artigos do Quarto Caderno. A atmosfera da prisão e, sobretudo, o seu impacto psicológico são transferidos a um poema:

\section{Soneto}

Vago por labirintos espelhados,

Feitos de duros bronzes e de prantos, Ando por descaminhos tais e tantos

Que seus desvios geram destroçados

Clarões de perdição, alcantilados

Declives enganosos, e mais quantos

Desconcertos couberem na alma, e espantos

Desfilando vertigens, e enforcados

Gritos que assomam, pedras proferidas

Como calhaus de noite, e maldição

Porejando da boca, e desferidas

Revista TextoPoético | ISSN: 1808-5385 | Vol. 21 (2o sem-2016) - p. 166. 
Perguntas de asas rotas - sim e não

Ceifando córneas, ossos e feridas -

E a dor do cravo assassinando a mão.

Rio, 22/2/69

Regimento Caetano de Faria (PELLEGRINO, 1993, p. 105)

As imagens de "labirintos espelhados" e "declives enganosos" simulam impressões e revelam incerteza. O "certo" é trocado pelo "duvidoso", desobedecendo ao conselho do ditado popular que recomenda o inverso. Percorre o poema a dor da dúvida, através das sensações que se misturam. Os labirintos são feios, "Feitos de duros bronzes e de prantos", há perigo nos "Declives enganosos, e mais quantos / Desconcertos couberem na alma, e espantos / Desfilando vertigens, e enforcados". Os gritos ajudam a compor imagens próprias às descrições de penalização, como as dos versos do Purgatório. Os três últimos versos unem a realidade daqueles dias - as perguntas sem resposta - e o significado mais abstrato do desespero, da falta de chão e de visão, da respiração presa.

Nos poemas de 1947 e 1964 ("Soneto" e "A CóleraEsperança"), aparecem situações e signos análogos. No entanto, esses dois poemas apresentam verbos complementados por objetos descrevendo ações completas, finitas, ainda que sejam em forma de quebras e explosões. Tomemos os versos das primeiras estrofes do "Soneto" de 1947, ao lado do primeiro quarteto do "Soneto" de 1969:

[1947]

Alguma coisa vai despedaçar-se

em mim. Tremem bandeiras degoladas.

Mastros acostumados às lufadas

do mar rangem no rumo de quebrar-se.

(PELLEGRINO, 1993, p. 151)

Revista TextoPoético | ISSN: 1808-5385 | Vol. 21 (2o sem-2016) - p. 167. 
[1969]

Vago por labirintos espelhados,

Feitos de duros bronzes e de prantos, Ando por descaminhos tais e tantos

Que seus desvios geram destroçados (PELLEGRINO, 1993, p. 105)

No primeiro bloco, vemos os sentimentos do poeta expressos através da associação da ideia de rompimento interno às imagens que descrevem forte movimento, no caso, do mar e do vento, capazes de desgastar bandeiras e mastros. A iminência da tempestade interna vem descrita pelas imagens dos instantes que antecedem um temporal de verdade, ao longo de todo o poema. No segundo bloco, o início do poema de 1969 descreve uma ação sem rumo e inconclusa (vagar por labirintos espelhados), graças à intensidade elaborada através do uso do verbo, pelo adjunto e pelo adjetivo - todos os elementos da oração que abre o poema descrevem a situação do ser "emparedado", sujeito literário presente no poema e dono somente das duas ações que aparecem no quarteto: vagar por labirintos e andar por descaminhos, metáforas das situações descritas em seguida, pontuadas pelas manifestações de espanto que o referido sujeito observa e com as quais compartilha, sem a possibilidade de escolha sugerida nos versos de 1947 ("O temporal vem perto. Abandonar-se / ao queixume das ondas agitadas / seria bom, talvez. [...]"). Se o sujeito no primeiro soneto parece estar diante de um mar de possibilidades assustadoras, emocionantes, animadoras, o sujeito no poema de 1968 está em âmbito muito reduzido (poderíamos facilmente supor o espaço entre quatro paredes), vigilante, ao sabor do sofrimento sufocado, sem explosão, sem conclusão. Não há expectativa de destroços, nem alívio temporário, como no primeiro texto.

Revista TextoPoético | ISSN: 1808-5385 | Vol. 21 (2o sem-2016) - p. 168. 
Quase desnecessário é mencionar os versos de "A CóleraEsperança" como uma espécie de mediação entre as duas situações. $\mathrm{O}$ poema de 1964 pode ser lido como manifestação de protesto vivificada pela ação de atirar contra ou jogar para longe, reiterada ao longo do poema. Não há nenhuma paralisia, como a que vem estampada nos versos de 1968, assim como a força incontida dos sentimentos que se fundem (cólera e esperança) estoura na ação deliberadamente provocativa - impossível não lembrar, durante a leitura de "A CóleraEsperança", das manifestações de rua que tiveram jovens atirando o que podiam contra o elemento repressor, enquanto a leitura do "Soneto" de 1968 parece ver um desses manifestantes na prisão, tolhido da visão do todo, do mundo exterior ao labirinto, da mira certeira, da direção, das perguntas e das respostas.

\section{Referências}

ADORNO, T. W. Palestra sobre lírica e sociedade. In: . Notas de

Literatura I. Trad. J. Almeida. São Paulo: Duas Cidades/Ed. 34, 2003, p. 6589.

ANDRADE, M. de. Poesias completas. São Paulo: Martins, 1966.

BETELLA, G. K. O rigor da resistência de Hélio Pellegrino na crônica de 1968 a 1988. In: XI Encontro Regional da ABRALIC, 2007, São Paulo. Anais do XI Encontro Regional da Associação Brasileira de Literatura Comparada. São Paulo: ABRALIC, 2007. v. 1.

ENTREVISTA concedida por Hélio Pellegrino, Otto Lara Resende, Paulo Mendes Campos e Fernando Sabino a Leda Nagle. DVD Entrevistas. In: RESENDE, O. L. Arquivinho de Otto Lara Resende. Org. L. C. Frota. Rio de Janeiro: Bem-Te-Vi, 2006. (Arquivinhos n. 3)

Revista TextoPoético | ISSN: 1808-5385 | Vol. 21 (2o sem-2016) - p. 169. 
PELLEGRINO, H. A intranquilidade cívica. Folha de S. Paulo, São Paulo, 18 ago. 1982, p. 3.

PELLEGRINO, H. Arquivinho de Hélio Pellegrino. Org. L. C. Frota. Rio de Janeiro: Bem-Te-Vi, 2004a.

PELlEGRINO, H. Lucidez embriagada. Org. A. Pellegrino. São Paulo: Planeta, 2004b.

PELLEGRINO, H. Minérios domados. Poesia reunida. Seleção e edição de H. Werneck. Rio de Janeiro: Rocco, 1993.

PELlEGRINO, H. Poema do príncipe exilado. Belo Horizonte: Edifício, 1947. (Cadernos Edifício)

PIRES, P. R. Hélio Pellegrino: a paixão indignada. 2. ed. Rio de Janeiro: Relume Dumará / Prefeitura do Rio de Janeiro, 1998. (Perfis do Rio, 20).

RANGEL, M. Otto, Paulo, Hélio, Fernando: encontro marcado de quatro mineiros. Manchete n. 1522, p. 115, 20 jun. 1981.

RESENDE, O. L. Arquivinho de Otto Lara Resende. Org. L. C. Frota. Rio de Janeiro: Bem-Te-Vi, 2006. (Arquivinhos n. 3)

VENTURA, Z. 1968: o ano que não terminou. A aventura de uma geração. Rio de Janeiro: Nova Fronteira, 1988.

Aprovado em 23 de maio de 2016.

Revista TextoPoético | ISSN: 1808-5385 | Vol. 21 (2o sem-2016) - p. 170. 